\title{
EXPERIMENTALJUSTIFICATION OF INDICATIVE MICROBIOLOGICAL VALUES FOR THE SAFETY OF WATER BODIES IN THE RECREATION AREAS
}

\author{
E.V. Drozdova, S.I. Sychik, V.V. Buraya, N.V. Dudchik, A.V. Firago, T.Z. Volk \\ RUE "Scientific Practical Centre of Hygiene" of the M inistry of Health \\ of the Republic of Belarus, the Republic of Belarus, M insk, 8, Academicheskaya St., 220012
}

The article provides the assessment of the microbiological values of water bodies if they are used for recreational purposes and distinguishes the epidemiologically significant parameters. In order to validate the indicative safety values taking into account the existing conditions of the recreational use of water we conducted the hygienic assessment of water in the water bodies used for recreational purposes under the indicative microbiological values (total microbial count, thermotolerant coliform bacteria, E. coli; enterococcus, spores of sulfite-reducing Clostridia; coliphages; Ps. aeruginosa) and the content of pathogenic microorganisms; also the microbiological profile of water was identified. The obtained data will be used to improve the system for monitoring of water bodies in the recreation areas.

Key words: recreational use of water, surface water bodies, monitoring, assessment of risks, microbiological health risks, indicative microorganisms.

The significant number of water bodies in the republic creates the prerequisites for the further development of recreation in the country. According to the official data the Republic of Belarus has more than 800 organized beaches used by population for cultural and recreational purposes. Currently, nearby the water bodies and water courses there are 18 republican recreational areas, and the recreational facilities in which about 109 thousand of places are created are located along the riversAt the same time, annually during the swimming season up to $30 \%$ of beaches are closed for population due to the incompliance with hygienic standards, first of all - under the microbiological indicators that evidence the urgency of problem of the safe recreational use of water resources. The absence of available recreational facility decreases the quality of life for population in summer and the tourist potential of the country, and the prohibition of swimming, as a rule, increases the probability of the unauthorized rest of population that also results in the increasing of risks to the health of population. The practice of the last years shows that the approaches for the operative monitoring of situation regulated by the applicable normative documents and taking the decision on the introduction (cancellation) of restrictive measures shall be actualized $[1,9]$.

The aforesaid determines the significance of the scientific and research work performed under the task 01.04 ONTP "Modern living conditions and preservation of health" for 2013-2015. Based on the results of experimental studies we will scientifically justify the methodology for assessing the risks to the health of population at the recreational water use, taking into account the degree of recreational load on water body, types of recreational water use (contact/non-contact), type of water body, availability of recreational facilities at the water body.

(C) Drozdova E.V., Sychik S.I., Buraya V.V., Dudchik N.V., Firago A.V., Volk T.Z., 2015

Drozdova Elena Valentinovna - candidate of medical science, head of laboratory for drinking water supply and sanitary protection of water reservoirs (e-mail: drozdovaev@ mail.ru; tel. +7 (375 17) 284 13 86).

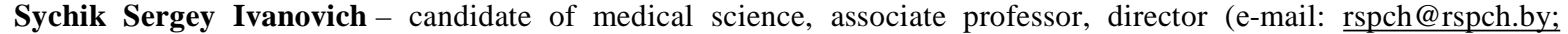
tel. +7 (375 17) 2840387$)$.

Dudchik Natalia Vladimirovna - candidate of biological science, associate professor, head of microbiology laboratory (e-mail: rspch@rspch.by; tel. +7 (375 17) 28413 85).

Buraya Valentina Vladimirovna - senior research assistant of laboratory for drinking water supply and sanitary protection of water reservoirs (e-mail: water@ rspch.by; tel. +7 (375 17) 28413 86).

Firago Anna Vladimirovna - trainee of the junior research assistant of laboratory for drinking water supply and sanitary protection of water reservoirs (e-mail: rspch@ rspch.by; tel. +7 (375 17) 28413 86).

Volk Tatyana Zdislavovna - junior research assistant of laboratory for drinking water supply and sanitary protection of water reservoirs (e-mail: rspch@ rspch.by; tel. +7 (375 17) 28413 86). 
Using the risk assessment methodology taking into account the certain existing conditions of recreational water use will allow for improving the surface water monitoring system used for recreational purposes applicable in the Republic of Belarus. This article provides the intermediate results of this work under the analysis of microbiological indicators of the water bodies' safety in order to assess the indicative parameters of the recreational water use safety.

Materials and methods. Experiment design justification. The surface water used for recreational purposes can contain a lot of both pathogen and opportunistic microorganisms. According to WHO, the most often conseqeuncy for health associated with the impact of recreational water contaminated by human biowaste are the small intestine diseases. We observed the cause-and-effect relationships between the fecal contamination or contamination entered the water from swimmers and infections of ear as well as the acute febrile respiratory diseases (hereinafter referred as AFRD) which is more serious consequency for health as gastroenteritis [12, 18, 20, 29].

The waste water is the main source of microbial surface water contamination. The micobiological composition of waste water depends, on the one hand, on the whole number of social aspects - number of population, level of social development and character of nutrition, on the other hand - on the content of organic substances, chemical composition, temperature and $\mathrm{pH}$. Also the climatic conditions, season, etc., affect the situation $[18,19]$.

The microorganisms contained in the waste water include the significant quantity of pathogen and opportunistic species. The most often detected pathogen microorganisms include the representatives of the following species: Salmonella, Shigella, Vibrio, Listeria, Leptospira, Bacillus, Mycobacterium, the opportunistic - Escherichia, Enterobacter, Citrobacter, Klebsiella, Yersinia, Pseudomonas, Aeromonas, Plesiomonas, Campylobacter, Staphylococcus and Streptococcus. The total microbial content of untreated waste water is $2.5 \cdot 10^{5}-$ $1 / 2 \cdot 10^{7} \mathrm{CFU} / \mathrm{ml}$, the content of $S$. faecallis is $1 \cdot 10^{2}$ $6 \cdot 10^{4} \mathrm{CFU} / \mathrm{ml}$, S. aureus - $6 \cdot 10^{1}-6 \cdot 10^{4} \mathrm{CFU} / \mathrm{ml}$, enterobacteria $-410^{4}-2 \cdot 10^{6} \mathrm{CFU} / \mathrm{ml}$, salmonella in the domestic waste water - at the level of $2.4 \cdot 10^{4}$ $\mathrm{CFU} / \mathrm{ml}$, Vibrio bacteria in the waste water not more than 10 in $1 \mathrm{ml}$.

Among the different types of pathogen microorganisms the special hazard for the health of human have the originators of intestinal infections which can be distributed by water and cause the development of such diseases as typhoid fever, paratyphoids, salmonellosis, dysentery, cholera, leptospirosis, campilobacteriosis, intestinal iersiniosis, viral hepatitis, poliomyelitis, intestinal enteroviral infections, etc.

The contamination of waste water with pathogen microorganisms is conducted in most of cases by the carriers of bacteria making up 1-2\% of population, people suffering by the erased forms of infectious diseases and persons in the incubation period of diseases. In the prevalence of salmonella the significant place is occupied by the waste of poultry factories, slaughterhouses, tanneries, cattle yards the contamination of which by these bacteria achieves almost $100 \%$. The microbiological studies on the determination of typhoid parasitic bacteria in the waste water samples taken from municipal sewage system demonstrated that $68.4 \%$ of them containd salmonellas of different serovars. The salmonellas were detected in $31.1 \%$ - medical institutions, $66.7 \%$ of waste water samples of slaughterhouses and $87.5 \%$ - of poultry killing plants. According the data from the studies of different authors more than 2600 strains of salmonellas were extracted from domestic waste water and serotyped. These srains belonged to 23-38 serovars but $S$. typhimurium prevailed.

The potential danger of domestic waste water is also associated with their contamination with enteroviruses Currently, we know more than 100 species of viruses pathogenic for human whivh are emitted from human body and contaminate the waste water; they include enteroviruses, polioviruses, hepatitis A virus, Coxsackie virus $\mathrm{A}$ and $\mathrm{B}$, rotaviruses, reoviruses and adenoviruses. Under the location they belong to enteroviruses and are extracted in $80-100 \%$ of the waste water samples. The emission of enteroviruses to waste water by patients and survivors can continue for several months. The waste water continuously contain the viruses of poliomyelitis, Coxsackie, ECHO; and the type composition of the waste water enteroviruses complies with such in the population of this territory. Up to $90 \%$ of extracted strains of polyviruses are vaccine strains. The concentration of enteroviruses in water varies depending on the epidemical situation, efficiency of treatment and disinfection of waste water and can very from $10^{3}$ to $10^{6}$ virions in one liter of untreated waste water and from $10^{2}$ to $10^{3}$ in the liter of water from the surface water body during the season of increase of morbidity with intestinal viral infections. The water clearing and discoloration stages at the water supply facilities of the centralized drinking water 
supply systems do not ensure the complete removal of viruses. The effect of the DNA-containing coliphages entrapment is $97-99 \%$, and poliovirus $83-93 \%$, compared to the concentration in initial water. In this relation it is necessary to have the drinking water disinfction ensuring the inactivation of viruses by $100 \%$.

The frequency of viruses' extraction from untreated waste water is $90-100 \%$ of the number of examined samples at the concentration of coliphages of up to $10^{4} \mathrm{BFU} / 100 \mathrm{ml}$ of analyzed water. After the mechanical treatment the viruses extraction frequency can be insignificantly increased due to the desagregation of large conglomerates and readsorption of viruses. After the biological treatment at the aeration stations the enteroviruses extraction frequency usually decreases to $40 \%$; herewith the viruses are removed by $75 \%$, and the DNA-containing coliphages - by $90 \%$. The content and frequency of the enteroviruses extraction from water bodies and drinking water can differ significantly that is determined by the seasonality of the prevalence of the different groups of viruses during year, sanitary-hygienic and epidemical situation in the upper areas of water course, violation of the technology for treatment and disinfection of drinking and waste water, emergencies at the water supply or sewage water treatment stations, outbreak of viral aquatic infections at this territory.

The viability of pathogen microorganisms in waste water together with qualitative and quantitative composition of microflora in many aspects determined their epidemical hazard. Their ability to survive is affected by many factors: content in water of antagonistically active flora and phages, availability of impurities and organic substances, temperature, $\mathrm{pH}$, insolation, concentration of dissolved oxygen, specific and strain peculiarities of pathogen microorganisms. The pathogen microorganisms preserve the viability and infectious activity in water for long-term period, for example, Campylobacter - up to 10 days, Shigella spp - up to 2 months, enteroviruses - up to one year.

When studying the species composition of the municipal mixed waste water of Minsk we also extracted the representatives of Klebsiella (K. pneumoniae, $K$. oxytoca, $K$. ozenae), Enterobacter ( $E$. agglomerans, E. cloacae, E. aerogenes), Citrobacter ( $C$. freundii). C. coli и $C$. yeyuni prevailed among Campylobacter bacteria. The Streptococcus bacteria were mainly representes by enterococcus $(60.5 \%)$. The examined muncipal mixed waste water of Minsk in $85 \%$ of samples demonstrated the
PCR-positive reaction for enteroviruses. The waste water of the medical and preventive treatment facility contained the significant amount of pathogen and opportunistic species. The most often found pathogen microorganisms included the representatives of Salmonella, Shigella, Vibrio, Listeria, Bacillus, opportunistic - Escherichia, Enterobacter, Citrobacter, Klebsiella, Yersinia, Pseudomonas, Aeromonas, Plesiomonas, Campylobacter, Staphylococcus and Streptococcus bacteria. The total microbial content of untreated waste water of the medical and preventive treatment facilities was $(4.5 \pm 1.0) \cdot 10^{6} \mathrm{CFU} / \mathrm{ml}$. The content of salmonellas was determined at the level of $2.4 \cdot 10^{3} \mathrm{CFU} / 100$ $\mathrm{ml}$. The enteroviruses were found in $40 \%$ of samples. When studying the species composition of the waste water of meat-packing plants we detected the representatives of Klebsiella which included $K$. pneumoniae, K. oxytoca, K. ozenae, Enterobacter - E. agglomerans, E. cloacae, E. aerogenes, as well as Citrobacter - C. freundii. The coliphages were determined at the level of $(4.1 \pm 0.6) \cdot 10^{4} \mathrm{BFU} / 100 \mathrm{ml}$, the enteroviruses were found in $60 \%$ of samples.

It is demonstrated that the strains of microorganisms extracted from waste water are resistant to the different types of antibiotics. We extracted the strains of Enterobacteriaceae having the high resistance to ampicillin and tetracycline as well as the moderate resistance to chloramphenicol (levomicetin).

The direct detection of the originators of infectious disease in natural water has a number of difficulties main of which include the instability and irregularity of the presence of pathogen microorganisms in the environment (especially during the interepidemical period), lower content of pathogen microorganisms at facilities compared to non-pathogen, competitive (antagonistic) action of non-pathogen microorganisms in relation to pathogen in the culture medium, etc. Due to this fact, the common global practice is to perform the current control by indirect method - under the detection of indicative microorganisms in the samples. If the samples did not comply with standard, the analysis for content of pathogen microorganisms was conducted.

Currently, the category of indicative microorganisms includes the representatives of human gut organisms: bacteria of Escherichia coli group (the group includes the bacteria of family Enterobacteriaceae, species Esherichia, Enterobacter, Citrobacter, Klebsiella), fecal Escherichia coli, enterococcus (fecal streptococcus), clostridia, Proteus bacteria, coliphage (phages of enteric bacterium). 
We demonstrated the availability of close direct correlation relationship between the quantity of sanitaryrepresentative microorganisms and the frequency of salmonella detection in the waste water of cities. The most often the salmonellas were found in the quantity of more than $10^{4} \mathrm{CFU} / \mathrm{l}$ and enterococcus of $10^{3}$ CFU/l. The detection of Coliform bacteria, enterococcus and coliphages is the indicator of fresh fecal contamination. The incompliance of water characteristics to the permissible levels of coliphages evidences the possible presence of enteroviruses in this sample.

World Health Organization proposes to control the recreational water based on the use of such indicators as the content of Escherichia coli (for fresh water) and enterococcus (sea water) in the samples of water. The recommended approximate values are expressed through 95 percentile of the quantities of indicative microorganisms per $100 \mathrm{ml}$ and represent the understandable levels of risk based on the conditions in which the exposure in the key studies was performed [18].

The European Union after the commencement of Directive 2006/7/EC dd. February 15, 2006 made the transition to the use of new approaches to the maintenance of control [4]. Only 2 microbiological indicators (enterococcus and Escherichia) are used for these purposes; they are assessed as the "most reliable indicative parameters for preventing the microbiological risks for the health of human and achievement of high level of protection". Based on the results of microbiological studies the water for swimming belongs to 4 classes.

In the Republic of Belarus [3] and CIS countries according to the applicable technical normative legal acts the indicators of microbial parameters are the thermotolerant coliform bacteria (TCB) and total coliforms (TCF). The determination of coliphages is used as the indicator of the viral contamination of water. This method is simplier than the extraction of enteroviruses.

Therefore, there are no universal criteria and approaches to the assessment of safety under the microbiological indicators $[2,6,8,10,13-15,21-$ 28]. According to $\mathrm{WHO}$, the recommended values shall be interpreted or modified in the context of regional and/or local factors, such as the nature and severity of local endemic diseases, behavior of population, pattern of impact, socio-cultural, economic, environmental and technical aspects, competitive risk for health from other diseases no associated with recreational water use.
Taking into account the aforesaid, it is necessary to conduct the studies under all the potential indicative parameters in order to review and justify scientifically the indicative parameters of the safety of surface water used for recreational purposes taking into account the existing conditions of recreational water use in the Republic of Belarus.

Subect of study. To select rhe water bodies in order to conduct the experimental studies we studied the data of laboratory analysis of water samples at the places of recreational water use provided by the institutions carrying out the state sanitary surveillance. The database for 90 regions of republic is created. Based on the analysis of information we justified the selection of typical water bodies used for recreational purposed for the conduction of studies. During selection we were guided by the following parameters: 1) type of water body (flowing/non-flowing); 2) rank of the recreational use of water body (republican, local level); 3) degree of recreational load on water body; 4) types of recreational water use prevailing at this water facility (contact/non-contact); 5) availability of recreational facilities in the area; 6) degree of sanitary reliability of water bodies (according to the sanitary service data).

We planned the examinations of surface water facilities used for recreational purposes (mainly at the territory of Minsk region) during 2 recreational seasons; the total volume of studies will be more than 300 of samples.

The subjects of study in 2013-2014 were the water facilities at the territory of Minsk region and Minsk: large rivers (Neman in the area of Stolbtsy, Berezina (Borisov), Ptich, Sluch (Soligorsk)), medium and small rivers (Isloch, Olshanka (Volozhin), Bobr, Shat (Pukhovichi)), as well as the water reservoirs Zaslavskoe, Komsomolskoe, Tsnyanskoe, Drozdy, Vyacha, Smolevicheskoe, Soligoskoe, Timkovichskoe, Krasnoslobodskoe. We conducted the expedition visits and examinations of water facilities in the recreational areas at the peak of swimming season (June-August) and took the samples of water for microbiologial analysis in the places for swimming and above the place for swimming.

Design of experiment. The studies of water samples are conducted under the wide list of potential indicative parameters of safety: total microbial count (TMC) in $1 \mathrm{ml}$; total coliforms (TCF), thermotolerant coliform bacteria (TCB); E. coli; enterococcus in $100 \mathrm{ml}$; spores of sulphite-reducing Clostridia; coliphages; Ps. aeruginosa. In addition, the content of pathogen microorganisms was deter- 
mined in the samples and the microbiological profile of water was identified.

The studies were performed in accordance with $[5,7,10]$. When carrying out the tests the standard equipment of microbiological laboratories was used. The following reagents and culture media were used during work: microbiological agar, bromothymol blue, glucose, potassium hydroxide, meat-and-peptone agar, meat-andpeptone broth, set of reagents for Gram's staining, $\alpha$-naphthol, dry enzymic peptone for bacteriological purposes, paper indicator systems PISglucose, PSI-oxidase, fuchsine-sulphite Endo medium, phenylenediamine compounds (tetramethyl-para-phenylendiamine hydrochloride or muriatic dimethyl-para-phenylendiamine), Kligler agar, Endo agar, Ploskirev agar.

TCF included the gram-negative, oxidasenegative bacillus not forming the spores which can grow on differential lactose media fermenting the lactose to acid and gas at $37 \pm 1^{\circ} \mathrm{C}$ during $24-48$ hours. TCB included bacteria having the TCF features as well able to ferment the lactose to acid and gas at $44 \pm 0.5^{\circ} \mathrm{C}$ during $24 \pm 2$ hours

The method is based on the filtration of established volume of water through membrane filters with further cultivation on selective medium, with identification and accounting of grown bacteria. The belonding of isolates to TCF and TCB was determined under the absence of oxidase activity, relation to Gram's staining, confirmation of ability to ferment lactose to acid and gas at $37 \pm 1^{\circ} \mathrm{C}$ during 24-48 hours and $44 \pm 0.5^{\circ} \mathrm{C}$ during $24 \pm 2$ hours. TCB producing indole from tryptophan at $44 \pm 0.5^{\circ} \mathrm{C}$ belonged to Escherichia coli. The belonging of isolates to enterococcus was determined visually, under the absence of catalase activity and relation to Gram's staining. The colonies specific for enterococcus: convex, with even edges, pink, light-pink, equally colored or with dark-red not clearly formed center.

Results and their discussion. The results of studies demonstrated that all the samples contained total coliforms, $71.4 \%$ of samples - thermotolerant coliform bacteria in the amount of more than $300 \mathrm{CFU} / 100 \mathrm{ml}$, among them $93.3 \%$ contained Escherichia coli. Further we performed the identification of colonies grown on the differential diagnostic media and included to total and и thermotolerant coliform bacteria. The isolated colonies were passed to the dishes with nondifferentiated nutrient MPA agar to obtain the daily monoculture of bacteria and were incubated at $37 \pm 1^{\circ} \mathrm{C}$ during $24 \pm 2$ hours. After the microscopy of Gram stained swabs we identified the bacteria using the microbiological biochemical analyzer VITEK (Biomerieux). The representatives of Escherichia, Citrobacter, Enterobacter, Klebsiella, Serratia were detected. The identification of pathogen microorganisms is perfomed.

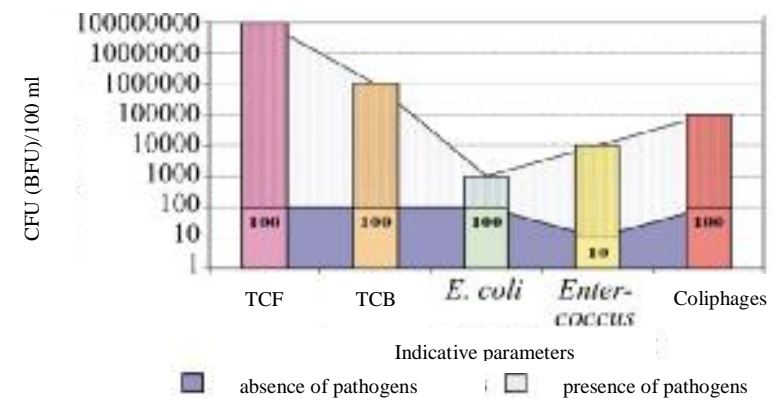

Fig. Dependence of values of the parameters of indicative microorganisms and presence of pathogen microorganisms in the water of water bodies

The intermediate results demonstrated that at TCF and TCB values of up to $100 \mathrm{CFU} / 100 \mathrm{ml}$, enterococcus and E. coli of up to $100 \mathrm{CFU} / 100 \mathrm{ml}$ we observed the complete absence of pathogen microorganisms in the disinfected waste water, during the determination of coliphages at the level of 100 $\mathrm{BFU} / 100 \mathrm{ml}$ and less no enteroviruses were found in the analyzed samples (see figure).

Conclusions. The obtained results will be used for the assessment of indicative microbiological parameters of safety in the dynamics of recreational period, their representation, including the dependence on the type of the used water bodies and load on the water body.

When selecting the indicative microorganisms it is necessary to be guided by the following conditions: they shall be easily detected and identified; have the nature similar to pathogen microorganisms; present in water in large quantities; have the same or even better viability than the pathogen microorganisms; and they shall be non-pathogen. 


\section{References}

1. Amvros'eva T.V., Bogush Z.F. Virusnoe zagrjaznenie vodnyh ob\#ek-tov: problemy i perspektivy ih sanitarno-virusologicheskogo kontrolja [Viral contamination of water bodies: problems and prospects of their sanitary and virological control]. Voda, 2008, no 12, pp. 10-13.

2. Buharin O.V., Nemceva N.V. Novye mikrobiologicheskie podhody k analizu sanitarno-gigienicheskogo i jekologicheskogo sostojanija prirodnyh vodoemov [New microbiological approaches to the analysis of sanitaryhygienic and environmental condition of natural water reservoirs]. Gigiena i sanitarija, 2002, no 5, pp. 22-24.

3. Sanitarnye normy i pravila «Gigienicheskie trebovanija k soder-zhaniju i jekspluatacii vodnyh ob\#ektov pri ispol'zovanii ih v rekreacion-nyh celjah» [Sanitary norms and regulations "Hygienic requirements to the maintenance and operation of water objects during their use for recreational purposes”]. utv. MZ RB post. № 238 ot 30.12.2008. Minsk, 2008.

4. Direktiva 2006/7/ES ot 15 fevralja 2006 g. kasajushhajasja upravlenija kachestvom vod dlja kupanija [Directive 2006/7/EC dd. February 2006 on the bathing water quality management]. Available at: http://eur-lex.europa.eu/legal-content/EN/ALL/?uri=CELEX:32006L0007.

5. Kriterii bezopasnosti dlja zdorov'ja naselenija vodnyh ob\#ektov Respubliki Belarus', ispol'zuemyh v rekreacionnyh celjah: instrukcija po primeneniju № 139-1207 [Criteria of safety for the health of population of the water bodies of the Republic of Belarus used for recreational purposes: application instructions No. 139-1207]. utv. Gl. gos. san. vrachom Resp. Belarus' 21.01.2008. Minsk, 2008.

6. Mamina L.V. Metodika ocenki sostojanija rekreacionnyh vodoemov urbanizirovannyh territorij: sanitarnogigienicheskij aspekt [Methods for the assessment of conditions of the recreation water reservoirs at the urban lands: sanitary and hygienic aspect]. Social'no-jekologicheskie tehnologii, Moscow, 2003, pp. 103-107.

7. Instrukcija po primeneniju № 025-0309. Metody obnaruzhenija vozbuditelej kishechnyh infekcij bakterial'noj prirody v vode pit'evoj, otkrytyh vodoemov, bassejnov i v stochnyh vodah [Application inctructions No. 025-0309. Methods for detection of activators of intestinal infections of bacterial origin in the potable water, open water reservoirs, basins and waste water]. utv. Gl. gos. san. vrachom RB 19.03.2010. Minsk, 2010.

8. Bojcov A.G., Lastovka O.N., Kashkarova G.P., Blagova O.E. Ocenka kachestva vody po biologicheskim pokazateljam: puti sovershenstvovanija [Water quality assessment under the biological indicators: the ways of improvement]. Gigiena i sanitarija, 2005, no 1, pp. 74-77.

9. Drozdova E.V., Buraja V.V., Kozlova T.O., Firago A.V. Rezul'taty gigienicheskoj ocenki vody vodnyh ob\#ektov v zonah rekreacii po mikrobiologicheskim pokazateljam kak osnova dlja nauchnogo obosnovanija indikatornyh pokazatelej bezopasnosti [Results of the hygienic assessment of water of water bodies in the recreation areas under the microbiological indicators as the basis for the scientific justification of the indicative safety values]. Zdorov'e i okruzhajushhaja sreda: sb. nauch. tr. / Resp. nauch. - prakt. centr gigieny; gl. red. S.I.Sychik. Minsk: GU «RNM», 2014, issue 24, vol. 1, pp. 7-11.

10. Instrukcija po primeneniju № 037-0409. Sanitarno-bakteriologicheskij, sanitarno-virusologicheskij i sanitarno-parazitologicheskij analiz vody poverhnostnyh vodoemov [Application instructions No. 037-0409. Sanitarybacteriological, sanitary-virological and sanitary-parasitological analysis of water in the surface water reservoirs], utv. Gl. gos. san. vrachom RB 08.05.2009. Minsk, 2009.

11. Shevcova N.S., Marcinkevich G.I., Drozdova E.V., Shushkova E.V. Turistsko-rekreacionnyj potencial i zonirovanie reki Zapadnaja Dvina dlja celej ustojchivogo prirodopol'zovanija [Tourist and recreation potential and zoning of Zapadnaya Dvina River for the purposes of sustainable use of natural resources]. Prirodnye resursy, 2011, no 2, pp. 92-102.

12. Assessing microbial safety of drinking water. Improving approaches and methods. OECD, Geneva, 2003, 295 p.

13. Marion J.W., Lee J., Lemeshow S., Buckley T.J. Association of gastrointestinal illness and recreational water exposure at an inland U.S. beach. Water Res., 2010, vol. 44 (16), pp. 4796-4804.

14. Chern E.C., Brenner K.P., L. Wymer, Haugland R.A. Comparison of Fecal Indicator Bacteria Densities in Marine Recreational Waters by QPCR. Water Quality Exposure and Health, 2009, vol. 1, pp. 203-214.

15. Papastergiou P., Mouchtouri V., Pinaka O., Katsiaflaka A., Rachiotis G., Hadjichristodoulou Ch. Elevated bathing-associated disease risks despite certified water quality: a cohort study. Int. J. Environ. Res. Public Health, 2012, vol. 9, pp. 1548-1565.

16. Soller J.A., Bartrand T., Ashbolt N.J., Ravenscroft J., Wade T.J. Estimating the primary ethiologic agents in recreational freshwaters impacted by human sources of faecal contamination. Water Res., 2010, vol. 44, pp. 4736-4747.

17. Griffith JF, Cao Y, McGee CD, Weisberg SB. 2009. Evaluation of rapid methods and novel indicators for assessing microbiological beach water quality. Water Res., vol. 43 (19), pp. 4900-4907.

18. Guidelines for safe recreational water environments. Vol. 1 Costal and fresh waters, WHO, Geneva, 2003, 219 p. Sons, Inc.

19. Haas CN, Rose JB, Gerba CP. 1999. Quantitative Microbial Risk Assessment. New York: John Wiley \& 
20. Health-based monitoring of recreational waters: the feasibility of new approach (The Annapolis Protocol'). Outcome of an expert consultation, Annapolis, USA Co-sponsored by USEPA. Geneva, 1999, 50 p.

21. Wade T.J., Calderon R.L., Brenner K.P., Sams E., Beach M., Haug-land R., Wymer L., Dufour A.P. High sensitivity of children to swimming-associated gastrointestinal illness: results using a rapid assay of recreational water quality. Epidemiology, 2008, vol. 19 (3), pp. 375-383.

22. Till D., McBride G., Ball A., Taylor K., Pyle E.Large-scale freshwater microbiological study: rationale, results and risks. Journal of Water and Health, 2008, vol. 6.4, pp. 443-460.

23. Leclerc H., Schwartzbrod L., Dei-Cas E. Microbial agents associated with waterborne diseases. Crit Rev Microbiol., 2002, vol. 28 (4), pp. 371-409.

24. Dorevitch S., Ashbolt N., Ferguson Ch., Fujioka R., McGee Ch., Soller J., Whitman R. Meeting Report: knowledge and gaps in developing microbial criteria for inland recreational waters. Environmental Health Perspectives, 2010, vol. 118, no 6, pp. 871-876.

25. Pruss A. Review of epidemiological studies on health effects from exposure to recreational water. Int. J. of Epidemiology, 1998, vol. 27, pp. 1-9.

26. Wade T.J., Calderon R.L., Sams E., Beach M., Brenner K.P., Williams A.H., Dufour A.P. Rapidly measured indicators of recreational water quality are predictive of swimming-associated gastrointestinal illness. Environmental Health Perspectives, 2006, vol. 114, no 1, pp. 24-28.

27. Stewart J. R., Gast R. J., Fujioka R. S. The costal environment and human health: microbial indicators, pathogens, sentinels and reservoirs. Environmental Health, 2008, vol. 7 (Suppl. 2), pp. 53-66.

28. Dorevitch S., Panthi S., Huang Y., Li H., Michalek A., Pratap P., Wroblewski M., Liu L., Scheff P., Li A. Water ingestion during water recreation. Water Res., 2011, vol. 45 (5), pp. 2020-2028.

29. Water recreation and disease. Plausibility of Associated infections: acute effects, sequelae and mortality. WHO, London, 2005, 239 p.

30. Colford J.M., Wade T.J., Schiff K.C., Wright C.C., Griffith J.F., Sandhu S.K., Burns S., Sobsey M., Lovelace G., Weisberg S.B. Water quality in-dicators and the risk of illness at beaches with nonpoint sources of fecal contamination. Epidemiology, 2007, vol. 18, pp. 27-35. 